\title{
Anticonvulsant Activity of Hydroalcoholic Extract of Ageratum Conyzoides L. (Asteraceae) in Mice
}

\author{
Patricia Randrianavony, PhD \\ Laboratoire de Pharmacologie Générale, de Pharmacocinétique et de \\ Cosmétologie, Faculté des Sciences, Université d'Antananarivo, Madagascar \\ Nat Quansah, PhD \\ School For International Training Study Abroad Summer Program \\ Madagascar: Traditional Medicine And Health Care Systems, \\ Antananarivo, Madagascar

\section{Roukia Djoudi, PhD}

Laboratoire Mixte International de Biotechnologie Environnement Santé (LMI-BES) Faculté des Sciences de Technologie et de l'Environnement, Université de Mahajanga, Madagascar

Nyamekye A. Quansah, Fanantenanirainy Randimbivololona, PhD

Laboratoire de Pharmacologie Générale, de Pharmacocinétique et de Cosmétologie, Faculté des Sciences, Université d'Antananarivo, Madagascar

Doi:10.19044/esj.2020.v16n18p114 URL:http://dx.doi.org/10.19044/esj.2020.v16n18p114

\begin{abstract}
This work aims to study the anticonvulsant activity in vivo of the hydro alcoholic extract of Ageratum conyzoides L. (ASTERACEAE) in mice. Seizure was induced by electric stimulation of animal ears and intraperitoneal injection of picrotoxin. The extract increases the seizure threshold and reduces picrotoxin-induced convulsion duration. Animals of control group reacted to electric shock of $10.67 \pm 0.74 \mathrm{mV}$, versus $14.33 \pm 0.64,22.67 \pm 1.28$ and 29.33 $\pm 0.64 \mathrm{mV}$ for the animals treated with the extract at doses 200,400 and 800 $\mathrm{mg} / \mathrm{kg}$ respectively $(\mathrm{P}<0.05)$. Duration of clonic seizure induced by picrotoxin decreases from $36.04 \pm 3.46 \mathrm{~s}$ in control group to $31.33 \pm 0.88,14.08 \pm 1.02$ and $10.07 \pm 1.31 \mathrm{~s}$ in the treated animals, while tonic seizure duration in control group is equal to $156.33 \pm 24.53 \mathrm{~s}$ versus $73.02 \pm 5.32 \mathrm{~s}$ and $29.67 \pm 3.59 \mathrm{~s}$ in the animals treated with the extract at doses 400 and $800 \mathrm{mg} / \mathrm{kg}$ respectively $(\mathrm{P}<0.05)$. Alkaloids in the extract might be responsible for this activity by blocking $\mathrm{Na}+$ or $\mathrm{K}+$ channels, it also might enhance GABA or inhibit glutamate action.
\end{abstract}


Keywords: Ageratum Conyzoides, Anticonvulsant, Electric Stimulation, Picrotoxin

\section{Introduction}

Convulsion is a sudden and involuntary contraction of skeletal muscle due to nervous hyper sensibility and hyper synchronization of brain neurons group (Vaughan \& Delanty, 2002). It often occurs during childhood, because of high temperature occurring during events such as viral infections. It can also happen as epileptic crises in children as well as in adult (Jones \& Jacobsen, 2007).

Two types of neuromodulators are found in the central nervous system: stimulating ones such as glutamate and inhibiting ones such as GABA ( $\gamma$ aminobutyric acid). This last neurotransmitter increases postsynaptic chloride influx. A disequilibrium between these two neurotransmitters in favor of glutamate or the deficiency of GABA enhances convulsion (Bertrand, 2006; Ben-Ari, 2007; Eusebio \& Micallef-Roll, 2010). It is a complicated mechanism, that is why most of anticonvulsant medicines are membrane stabilizer (Wilcock \& Twycross, 2011), glutamate antagonist, or influence GABA system (Deshmukh et al., 2011).

Ageratum conyzoides L. (Asteraceae), is an annual herbaceous plant with a long history of traditional medicinal uses in several countries. It is widely used in traditional medicine by various cultures worldwide, although applications vary from region to region. In Central Africa it is used to treat pneumonia, but the most common use is to cure wounds and burns (Durodola, 1977). Traditional communities in India use this species as a bactericide, antidysentery, and antihelminthic (Borthakur \& Baruah, 1987), it also has insecticidal and nematocidal activity (Ming, 1999). In Cameroon and Congo, A. conyzoides is used to treat fever, rheumatism, headache, and colic (Menut et al., 1993; Bioka et al., 1993). An ethnopharmacological survey that we have conducted among the population of Andasibe (Madagascar) revealed its use to prevent seizure crisis. Decoction of the whole plant is regularly given to children who have convulsion problem.

The objective of this study is to evaluate the anticonvulsant activity of the hydroalcoholic extract of $A$. conyzoides. Different methods, for example, transcranial neurostimulation (Sayyah et al., 2011), or injection of convulsioninducing drugs such as pentilenetetrazole, picrotoxin (Löscher \& Schmidt, 1988; Visweswari G. et al., 2010)), pilocarpine (Cavalheiro et al., 1982), or bicuculline (Johnston, 2013), can be used to evaluate the anticonvulsant activity of a product. In this study electric shock and i.p., injection of picrotoxin were used to induce convulsion in mice. 


\section{Materials And Methods}

\section{Extraction and phytochemical screening}

The entire A. conyzoides plant was collected at Andasibe (Madagascar) and a voucher specimen was identified at the herbarium of Parc Botanique et Zoologique de Tsimabazaza (PBZT) (Antananarivo, Madagascar). The plant was dried in shade, at room temperature, then ground with a grinder "BROOK CROMPTON C, Série 2000". The powder was macerated in a mixture of ethanol and water (60:40), at room temperature, for 3 days. The macerate was filtrated and evaporated to dryness with a vacuum evaporator, Rotavapor (BÜCHI), at $80^{\circ} \mathrm{C}$. The dry extract was dissolved in distilled water for the anticonvulsant tests. Phytochemical screening was carried out to determine the main chemicals in the extract. Specific reagents were used, they react with specific chemical family to give a characteristic color or precipitation. Dragendorff and Wagner reagents were used to detect alkaloids, Fehling liquor for reducing sugars, chlorhydric acid for anthocyanins, gelatin for tannins, sulfuric acid and magnesium ribbon for flavonoids, and Salkowski reaction using concentrated sulfuric acid and Lieberman Burchard, using anhydrous acetic and sulfuric acid for steroids and terpenoids (Fong et al, 1977). All reagents used in this study were prepared using chemicals from Sigma-Aldrich ®.

\section{Experiment animals}

Male mice of Swiss strain aged 6 to 8 weeks and weighing between 20 and $25 \mathrm{~g}$ were used in this experiment. The animals were fastened for $12 \mathrm{~h}$ prior to the test and divided into 4 groups of 6 animals per group, 1 control group which received $10 \mathrm{ml} / \mathrm{kg}$ of distilled water, and the 3 other groups were treated with the extract at doses 200,400 and $800 \mathrm{mg} / \mathrm{kg}$ in $10 \mathrm{ml} / \mathrm{kg}$ distilled water, respectively, administered orally.

The experiments were conducted following the guidelines of the ethic committee of Sciences Faculty, University of Antananarivo, Madagascar (Ref: CE/Fac Sciences/Pharmacol./001, 02/21/2019).

\section{Study of $A$. conyzoides activity on convulsion threshold}

One hour after oral administration of the extract and water, electrodes rubbed with conductive gel (TransCard $($ ) ) were fixed on the ear lobe of the animals. A neurostimulator (Harvard®) was used to deliver an electric shock of $20 \mathrm{~ms}$ width and $60 \mathrm{~Hz}$ square wave to the mice's ear lobe. To determine the seizure threshold, the stimulation was started at $5 \mathrm{mV}$ and increased until the animal reacted to the stimulation (Branco et al., 2009; Gerstner et al., 2014).

4. Study of $A$. conyzoides activity on picrotoxin-induced convulsion

A. conyzoides hydroalcoholic extract activity was studied on picrotoxin-induced tonico-clonic convulsion. One hour after the 
administration of distilled water and extract, $4 \mathrm{mg} / \mathrm{kg}$ of picrotoxin (RBI $\circledR$ Research Biochemicals Incorporated) dissolved in distilled water were injected intra peritoneally to each animal. The animals were, then, put in individual cages for 30 minutes observation. The latency time and the duration of any convulsion sign were noted (Akula et al., 2007).

\section{Expression and analysis of results}

Results were expressed as $(\mathrm{m} \pm \bar{\sigma})$, with $\mathrm{n}=6$, the means were compared using Student ' $t$ ' test. The difference is considered as significant for $\mathrm{P}<0.05$ when compared with control group (* $\mathrm{P}<0.05$, ** $\mathrm{P}<0.01$, *** $\mathrm{P}<0.001)$.

\section{Results}

\section{Results of the phytochemical screening}

The phytochemical screening revealed the presence of high concentration of alkaloids, and small amount of reducing sugars, anthocyanins, tannins, flavonoids, steroids and terpenoids.

\section{Effect of $A$. conyzoides activity on convulsion threshold}

Oral administration of $A$. conyzoides hydroalcoholic extract increases the convulsion threshold in mice. The control group animals reacted to an electric shock of $10.3 \pm 0.5 \mathrm{mV}$, versus $14.6 \pm 0.2,22.3 \pm 0.3$ and $28.1 \pm 0.2$ $\mathrm{mV}$ for the animals treated with the extract at doses 200,400 and $800 \mathrm{mg} / \mathrm{kg}$ respectively $(\mathrm{P}<0.05)$ (Figure 1$)$.



Figure 1. Single electric shock induced convulsion threshold in control group animals and animals given A. conyzoides hydroalcoholic extract at 200 , 400 and 800 $\mathrm{mg} / \mathrm{kg}$ administered orally ( $\mathrm{m} \pm \bar{\sigma} ; \mathrm{n}=6 ; * * * \mathrm{P}<0.001$ as compared to control group).

\section{Effect of A. conyzoides on the duration of picrotoxin-induced clonic convulsion}

Administered intra peritoneally, picrotoxin induces generalized convulsion. Hydroalcoholic extract of $A$. conyzoides, administered orally at doses 200,400 and $800 \mathrm{mg} / \mathrm{kg}$ reduces the duration of clonic convulsion, from 
$40.1 \pm 0.5 \mathrm{~s}$ in the control group to $18.2 \pm 0.2,16.3 \pm 0.2$ and $12.5 \pm 0.3 \mathrm{~s}$ respectively in the treated animals $(\mathrm{P}<0.05)$ (Figure 2$)$.



Figure 2. Duration of picrotoxin-induced clonic convulsion in control group animals and animals treated with $A$. conyzoides hydroalcoholic extract at $\mathbf{2 0 0}, 400 \quad$ and $800 \mathrm{mg} / \mathrm{kg}$ administered orally $(\mathrm{m} \pm \bar{\sigma} ; \mathrm{n}=6 ; * * * \mathrm{P}<0.001$ as compared to control group).

\section{Effect of $A$. conyzoides on the duration of picrotoxin-induced tonic convulsion}

Hydroalcoholic extract of A. conyzoides, administered orally, decreases the duration of tonic convulsion induced by picrotoxin administered intra peritoneally. The animals in the control group convulse during $192.5 \pm \mathrm{s}$ versus $161 \pm 4.2,73.2 \pm 1.0$ and $24.8 \pm 0.3 \mathrm{~s}$ in the animals treated with the extract at doses 200, 400 and $800 \mathrm{mg} / \mathrm{kg}$ respectively $(\mathrm{P}<0.05)$ (Figure 3 ).

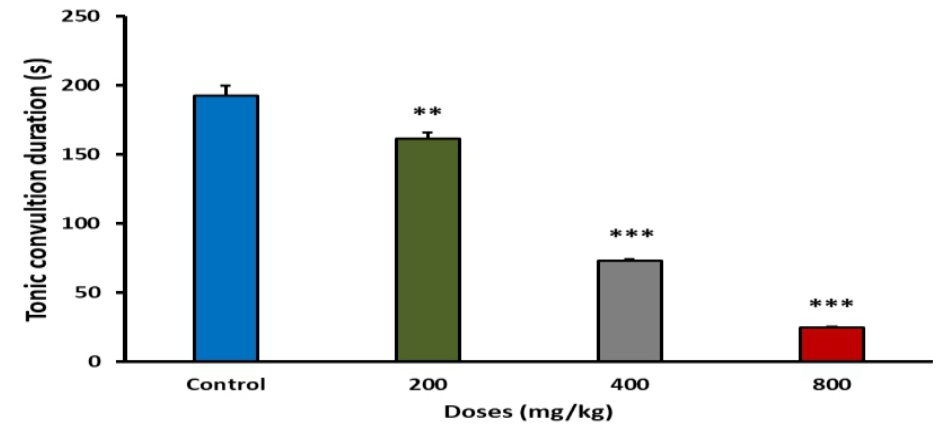

Figure 3. Duration of picrotoxin-induced tonic convulsion in control group animals and animals treated with $A$. conyzoides hydroalcoholic extract at $200 \square, 400$ and $800 \mathrm{mg} / \mathrm{kg}$ administered orally $(\mathrm{m} \pm \bar{\sigma} ; \mathrm{n}=6 ; * * \mathrm{P}<0.01 ; * * * \mathrm{P}<0.001$ as compared to control group).

\section{Discussion}

Ageratum conyzoides hydroalcoholic extract was tested on electric shock and picrotoxin induced convulsion in mice. Administered orally, it reduces seizure crisis. It increases the seizure threshold in mice and decreases 
the duration of clonic and tonic convulsion induced by picrotoxin administered intra peritoneally.

In this study, electric shock on mice ear lobe was used because it induces convulsion in small animals in vivo (Gerstner et al., 2014). Electric shock increases sodium and potassium conductance which leads to tonic and clonic convulsions. Increasing electric shock intensity facilitates opening of voltage-dependent ionic channels (Kampa et al., 2004; Lockman \& Fisher, 2009). Administered before electric shock, A. conyzoides hydroalcoholic extract increases neuron threshold thereby protecting animals from convulsion. This may be due to the neuronal membrane stabilizing or muscle contraction inhibition. Threshold increase could be due to ionophore blockage inhibiting depolarization like carbamazepine or phenytoin which blocks natrium channels (Armijo et al., 2005). Potassium channel blockage may also be involved in this mechanism. Molecules in the extract might block potassium channels which leads to threshold increase and stabilizing neuron membrane (Holmes \& Zhao, 2008). It is also possible that an active compound in A. conizoides blocks calcium voltage opening channels, therefore inhibits glutamate release from presynaptic neuron and muscle contraction (Krishnan \& Bazhenov, 2011).

The central nervous system's functions depend on a dynamic balance between exciting and inhibiting systems, where GABA is the most important in the inhibiting system and glutamate in the exciting system. An imbalance between the two mediators, in favour of excitatory system, leads to convulsion crisis (Raimondo et al., 2015). Injected intra peritoneally, picrotoxin gets to the central nervous system and blocks GABA receptors decreasing $\mathrm{Cl}^{-}$input, thereby increasing neuron excitability, which leads to seizure crisis with tonic and clonic convulsion (Barnard et al., 1998; Goutman \& Calvo, 2004). Since oral administration of $A$. conyzoides extract inhibits seizure crisis, one can advance the hypotheses whereby $A$. conyzoides extract might bloc picrotoxin action on GABA receptors, increase pre-synaptic release of GABA or inhibit degradation of GABA in synaptic cleft like vigabatrin by inhibiting GABAaminotransferase. In this case, the increase of GABA concentration in the synaptic cleft leads to increase in $\mathrm{Cl}^{-}$input, stabilizing the membrane, thereby inhibiting seizure crisis (Macdonald \& Kelly, 1995; Czapiński et al., 2005).

Furthermore, AMPA receptor activation is responsible for rapid excitation responses, and glutamate fixation on this receptor increases $\mathrm{Na}^{+}$ neuronal input, leading to neurone hyperexcitability. This provokes seizure crisis (Twomey et al., 2017). An active compound in A. conyzoides extract might bind to this receptor and inhibits seizure crisis.

Another possibility is that an active compound in A. conyzoides extract might inhibit glutamate release, by binding to NMDA receptor. Decreases of $\mathrm{Ca}^{2+}$ input in post synaptic neuron will decrease recycling of glutamate in 
presynaptic neuron. This will lead to decrease of glutamate released into the synaptic cleft (Wang, 2013; Guo et al., 2017).

Flavonoïds, alkaloids or terpenes might be responsible for the anticonvulsant activity of A. conyzoides hydroalcoholic extract. As reported by Rasilingam et al. (2009), gossypin, a flavonoid isolated from Hibiscus vitifolius L. (Malvaceae) protects mice from MES-induced seizure; similarly flavonoids isolated from Nauclea latifolia Sm. (Rubiaceae) protect mice against MES-induced seizures through GABA or by inhibiting sodium channels (Bum et al.,2009), and the flavonoid, galangin, isolated from Acorus calamus L. (Acoraceae) act through GABA receptor (Jayaraman et al., 2010). Alkaloids also have been reported to be responsible for anticonvulsant activity. For example: Da Cruz et al. (2013) reported that the alkaloid piperine protects mice from MES-induced seizure through GABA receptor; while Riberio and Laite (2003) have noted that the alkaloid nantenine decreases $\mathrm{Ca}^{2+}$ influx in post synaptic neuron. Chen et al., (1996) also reported that the alkaloid ibogaine protects mice from MES-induced seizure by blocking NMDA receptor. The anticonvulsant activity of terpenes also have been reported. According to De Sousa et al. (2006), the terpene citronellol has a protective activity against MES-induced seizure by $\mathrm{Na}^{+}$channel inhibition; while linalool, a terpene isolated from Lavandula officinalis protects mice from MES-induced seizure crisis by inhibiting NMAD receptor (ARZI et al., 2011).

\section{Conclusion}

The results of this work show that $A$. conyzoides hydroalcoholic extract possesses anticonvulsant effect. The flavonoïds, alkaloids or terpenes might be responsible for its anticonvulsant activity. At this stage, it is difficult to determine exactly what the active compounds are. Further studies are necessary to identify them and determine their mechanisms of action.

\section{References:}

1. Akula, K.K., Dhir, A. \& Kurbami, S.K. (2007). Pro convulsant effect of cefazolin sodium against picrotoxin-induced convulsion in mice. Ind. J. Exp. Biol., 45 (8):720-725.

2. Armijo, J.A., Shushtarian, M., Valdizan, E.M., Cuadrado, A., De Las Cuevas, I. \& Adín, J. (2005). Ion channels and epilepsy. Curr. Pharm. Des., 11(15):1975-2003.

3. Arzi A., Ahamehe M. \& Sarahroodi S. (2011). Effect of hydroalcoholic extract of Lavandula officinalis on nicotine-induced convulsion in mice. Pakistan journal of biological sciences, 14: 63440. 
4. Barnard, E.A., Skolnick, P., Olsen, R.W., Mohler, H., Sieghart, W., Biggio, G., Braestrup, C., Bateson, A.N. \& Langer, S.Z. (1998). International Union of Pharmacology. XV. Subtypes of gammaaminobutyric acid A receptors: classification on the basis of subunit structure and receptor function. Pharmacol. Rev., 50:291-313.

5. Ben-Ari, Y. (2007). Le GABA, un transmetteur pionnier pour la construction du cerveau. Médecine/Sciences, 23:751-755.

6. Bertrand, D. (2006). Importance des canaux ioniques dans les epilepsies et leur transmission génétique. Epileptologie, 23:170-173.

7. Bioka, D., Banyikwa, F.F. \& Choudhuri, M.A. (1993). Analgesic effects of a crude extract of Ageratum conyzoides in the rat. Acta Hort., 332:171-176.

8. Borthakur, N. \& Baruah, A.K.S. (1987). Search for precocenes in Ageratum conyzoides Linn. of North-East India. J. Indian Chem. Soc., 64:580-581.

9. Branco, C. M., Figueiredo, I. V., Alves, G., Falcão, A.C. \& Caramona, M.M. (2009). The maximal electroshock seizure (MES) model in the preclinical assessment of potential new antiepileptic drugs, Methods and Findings. Experimental and Clinical Pharmacology, 31(2):101106.

10. Bum E.N., Taiwe G.S., Moto F.C.O., Ngoupaye G.T., Nkantchoua G.C.N., Pelanken M.M., Rakotonirina S.V. \& Rakotonirina A. (2009). Anticonvulsant, anxiolytic, and sedative properties of the roots of Nauclea latifolia Smith in mice. J. Epilepsy Behav., 15: 434-40

11. Cavalheiro, E.A., Riche, D.A. \& Le Gal La Salle, G. (1982). Longterm effects of intrahippocampal kainic acid injection in rats: a method for inducing spontaneous recurrent seizures. Electroencephalogr. Clin. Neurophysiol., 53:581-589

12. Chen K., Kokate T. G., Donevan S. D., Carroll F. I., Rogawski M. A. (1996). Ibogaine block of the NMDA receptor: in vitro and in vivo studies. Neuropharmacology, 35:423-431.

13. Czapiński, P., Blaszczyk, B. \& Czuczwar, S.J. (2005). Mechanisms of action of antiepileptic drugs. Curr. Top. Med. Chem., 5(1):3-14.

14. da Cruz G. M. P., Felipe C. F. B., Scorza F. A., da Costa M. A. C., Tavares A. F., Menezes M. L. F. et al. (2013). Piperine decreases pilocarpine-induced convulsions by GABAergic mechanisms. Pharmacol. Biochem. Behav.,104:144-153.

15. De Sousa D.P., de Farias Nóbrega F.F. \& de Almeida R.N. (2007). Influence of the chirality of (R)-(-)- and (S)-(+)-carvone in the central nervous system: a comparative study. Chirality, 19: 264-268.

16. Deshmukh, R., Alok T.S. \& Dewangan, D. (2011). Mechanism of action of anticonvulsant drugs: a review IJPSR, 2(2):225-236. 
17. Durodola, J.J. (1977). Antibacterial property of crude extracts from herbal wound healing remedy-Ageratum conyzoides. Planta Medica, 32:388-390.

18. Eusebio, A. \& Micallef-Roll, J. (2010). Glutamate et grandes fonctions cérébrales. La lettre du neurologue, 14(11):7-12.

19. Fong, H.H.S., Tin-Wa, M. \& Farnsworth, N.R. (1977). Phytochemical screening plants. Rev. Pharamcol. University of Illinois, Chicago (USA), 275-277.

20. Gerstner, J. R., Smith, G.G., Lenz, O., Perron, I.J., Buono, R.J. \& Ferraro, T.N. (2014). BMAL1 controls the diurnal rhythm and set point for electrical seizure threshold in mice. Front. Syst. Neurosci., 48-51.

21. Goutman, J.D. \& Calvo, D.J. (2004). Studies on the mechanisms of action of picrotoxin, quercetin and pregnanolone at the GABA 1 receptor. Br. J. Pharmacol., 141:717-727.

22. Guo, H., Camargo, L.M., Yeboah F., Digan M.E., Niu H., Pan Y., Reiling S., Soler-Llavina G., Weihofen W.A., Wang H.R., Shanker Y.G., Stams T. \& Bill, A. (2017). A NMDA-receptor calcium influx assay sensitive to stimulation by glutamate and glycine/D-serine. Scientific Reports 7(Art. 11608):1-13.

23. Holmes, G.L. \& Zhao, Q. (2008). Choosing the correct AED: from animal studies to the clinic. Pediatr. Neurol., 38 (3):151-162.

24. Jayaraman R., Anitha T., Joshi V.D. (2010). Analgesic and anticonvulsant effects of Acorus calamus roots in mice. Int. J. of Pharm. Tech. Res., 2: 552-555.

25. Johnston, G. A. R. (2013). Advantages of an antagonist: bicuculline and other GABA antagonists. Br. J. Pharmacol., 169(2):328-336.

26. Jones, T. \& Jacobsen, S.J. (2007). Childhood Febrile Seizures: Overview and Implications. Int. J. Med. Sci., 4(2):110-114.

27. Kampa, B.M., Clements, J., Jonas, P. \& Stuart, G.J. (2004). Kinetics of $\mathrm{Mg}^{2+}$ unblock of NMDA receptors: implications for spike-timing dependent synaptic plasticity. J. Physiol., 556:337-45.

28. Krishnan, G.P. \& Bazhenov, M. (2011). Ionic dynamics mediate spontaneous termination of seizures and postictal depression state. J. Neurosci., 31: 8870-8878.

29. Lockman, J. \& Fisher, R.S. (2009). Therapeutic brain stimulation for epilepsy. Neurol. Clin., 27(4):1031-1040.

30. Löscher, W. \& Schmidt, D. (1988). Which animal models should be used in the search for new antiepileptic drugs? A proposal based on experimental and clinical considerations. Epilepsy Res., 2:145-181.

31. Macdonald, R.L. \& Kelly, K.M. (1995). Antiepileptic drug mechanisms of action. Epilepsia, 36(2):2-12. 
32. Menut, C., Sharma, S. \& Luthra, C. (1993). Aromatic plants of tropical central Africa, Part X-Chemical composition of essential oils of Ageratum houstonianum Mill. and Ageratum conyzoides L. Cameroon. Flavour Fragrance J., 8(1):1- 4.

33. Ming, L.C. (1999). Ageratum conyzoides: A tropical source of medicinal and agricultural products. In Perspectives on new crops and new uses. ASHS Press, J. Janick (ed.), Alexandria, 469-473.

34. Raimondo, J.V., Burman, R.J., Arieh, A., Katz, A.A. \& Akerman, C.J. (2015). Ion dynamics during seizures. Front Cell Neurosci., 9(419):114.

35. Rasilingam D., Duraisamy S. \& Subramanian R. (2009). Anticonvulsant activity of bioflavonoid gossypin. Bangladesh J. Pharmacol., 4:51-4.

36. Ribeiro R.A. \& Leite J.R. (2003). Nantenine alkaloid presents anticonvulsant effect on two classical animal models. Phytomedicine. 10:563-568.

37. Sayyah, M., Khodaparast, A., Yazdi, A. \& Sardari, S. (2011). Screening of the anticonvulsant activity of some plants from FABACEAE family in experimental seizure models in mice. Daru, 19(4):301-305.

38. Twomey, E.C., Yelshanskaya, M.V., Grassucci, R.A., Frank, J. \& Sobolevsky, A.I. (2017). Channel opening and gating mechanism in AMPA-subtype glutamate receptors. Nature, 549(7670):60-65.

39. Vaughan, C.J. \& Delanty, N. (2002). Pathology of acute seizure. Seizure: Medical causes and management. Ed. Human Press (Totowa). Chap. 2:7-23.

40. Visweswari G., Siva PK, Lokanatha V., Rajendra W. (2010). The antiepileptic effect of Centella asiatica on the activities of $\mathrm{Na}+\mathrm{K}+-$ ATPase, Mg2+-ATPase, and $\mathrm{Ca} 2+-A T P a s e$ in rat brain during pentylenetetrazol-induced epilepsy. Indian J. Pharmacol., 42:82-6.

41. Wang, C. (2013). Critical Regulation of Calcium Signaling and NMDA-type Glutamate Receptor. In Developmental Neural Toxicity. J. Drug Metab. Toxicol., 4(3):151-156.

42. Wilcock, A. \& Twycross, R. (2011). Therapeutic Reviews. Journal of pains and symptom management, 42(5):788-804. 